\title{
Quantitative Analysis of Selected Heavy Metals in Samples of Branded and Unbranded Cow Milk in Selected Areas of Kaduna Metropolis
}

\author{
I.Sani $^{{ }^{*}}$, B El-yaqub ${ }^{1}$, SO Okeniyi ${ }^{1}$, AB Shehu ${ }^{2}$ \\ ${ }^{1}$ Department of Chemistry, Faculty of Science, Nigerian Defence Academy, Kaduna, Nigeria \\ ${ }^{2}$ Food Technology and Home Economics Department, NAERLS/ABU Zaria, Kaduna, Nigeria
}

*Corresponding Author: I. Sani, Department of Chemistry, Faculty of Science, Nigerian Defence Academy, Kaduna, Nigeria.

\begin{abstract}
Twenty four (24) samples of unbranded cow milk and fifteen (15) various brands of branded co $w$ milk (BCM) were used in this study. Atomic absorption spectrophotometric method using wet digestion analytical method was made use of to determine the concentration of $\mathrm{Pb}, \mathrm{Cr}$, and $\mathrm{Cd}$ in the samples. The results indicates that the main concentration of $\mathrm{Cd}, \mathrm{Pb}$ and $\mathrm{Cr}$ were $0.0014 \mathrm{ppm}, 0.0017 \mathrm{ppm}$ and 0.0028 for UCM and 0.0017ppm, 0.0015ppm and 0.0015ppm for BCM respectively. The concentration of the heavy metals were within limit stipulated by WHO and the Nigerian industrial standards (NIS) with the exception of one sample were Cd level was above limit.
\end{abstract}

Keywords: Heavy metals, Wet digestion, cow milk, Atomic absorption spectrophotometric.

\section{INTRODUCTION}

Milk is a food of outstanding interest and has been taken by humans since the earliest pre-historic times and still forms the basis of most nation economies (Alfa, 1987). Milk is considered to be a complete food for young animals and of high nutritional value to humans. The constituents of milk include protein, fat, total solid, lactose, etc. Also, milk contains hundreds of minor constituents which include milk fat, vitamins, metal ion and flavor compounds (Armstrong, 1995). Animals are reared to produce milk for consumption by humans, although, cow is by far the most important in commercial terms (Adams and Moses, 1995) and White Fulani (Bunaji) as native breed in west Africa was recognized as the principal producer (Adeneye, 1989). Trace metals are a general collective term applying to the group of metals and metalloids with an atomic density greater than $6 \mathrm{~g} / \mathrm{cm}$. This term is widely recognized and usually applied to the elements such as cadmium $(\mathrm{Cd}), \mathrm{Cu}, \mathrm{Fe}$, lead $(\mathrm{Pb})$, and $\mathrm{Zn}$ which are commonly associated with pollution and toxicity problems (Malhatet al., 2012). One of the main problems with metals is their ability to bio-accumulate. Metal residues in milk are of particular concern because milk is largely consumed by infants and children (Tripathi et al., 1999). The food chain is an important source of $\mathrm{Cd}$ and $\mathrm{Pb}$ accumulation, especially for plants grown on polluted soils. Significant amounts of $\mathrm{Cd}$ and $\mathrm{Pb}$ can be transferred from contaminated soil to plants and grass, causing accumulation of these potentially toxic metals in grazing ruminants, particularly in cattle (Lópezet al., 2003). Accumulation of $\mathrm{Cd}$ and $\mathrm{Pb}$ in ruminants causes toxic effects in cattle, but also in humans consuming meat and milk contaminated with toxic metals (González-Weller et al., 2012). $\mathrm{Cd}$ and $\mathrm{Pb}$ are amongst the elements that have caused the most concern in terms of adverse effects on human health. This is because they are readily transferred through food chains and are not known to serve any essential biological function. Lead is a pervasive and widely distributed environmental pollutant with no beneficial biological roles. The poisoning is more common in farm ruminants, which are considered most susceptible to the toxic effects of lead (Swarup et al., 2005).

\section{MATERIAL AND MethodS}

\subsection{Sample Collection and Preparation}

Polyethylene sampling bottles were soaked in $20 \% \mathrm{HNO}_{3}$ for 24 hours and rinsed with deionized water before collection of raw milk in order to avoid possible contamination. Sampling was carried 
out across various milk markets in Kaduna metropolis, three replicate samples were collected at each sampled area which included Railway market, Rido, Kasuwar Barchi, Zango Cattle Market, Kajuru, Panteka, Kasuwar Magani and Kaduna Central Market. Branded Cow Milk. (BCM) were purchased across the counter at various supermarket in Kaduna metropolis. Each of the brand was purchased three times at different time interval and each with different batch number, (Farid 2010). The name of each Sample was replaced with an alphabet from A- Z for unbranded and A-O for branded. Names were followed by $\mathrm{U}$ meaning the product is Unbranded, or B meaning that the product is branded.

\subsection{Sample Digestion}

Each sample $\left(1 \mathrm{~cm}^{3}\right)$ was digested with $5 \mathrm{~cm}^{3}$ of concentrated hydrochloric acid $(\mathrm{HCl})$ and $5 \mathrm{~cm}^{3}$ of concentrated perchloric acid $\left(\mathrm{HClO}_{4}\right)$, all analytical grades. The digested samples were quantitatively transferred into $50 \mathrm{~cm}^{3}$ flask, made up to the mark with distilled water and stored in $50 \mathrm{~cm}^{3}$ propylene bottles. This was digested by heating the content in the beaker to nearly dryness. After evaporation and cooling, $20 \mathrm{~cm}^{3}$ of distilled water was added to the beaker, stirred and filtered into $50 \mathrm{~cm}^{3}$ volumetric flask and filled to the mark with distilled water. It was then transferred into $50 \mathrm{~cm}^{3}$ sample bottle, the digested sample was allowed to cool at room temperature. A specified amount of distilled water was added into the digested residue and filtered through what man filter paper No 1 . The volume of the filtrate was made up to $100 \mathrm{ml}$ using distilled water and the solution was further diluted before determinations of lead $(\mathrm{Pb})$, Chromium $(\mathrm{Cr})$ and Cadmium $(\mathrm{Cd})$ using Flame Atomic Absorption Spectroscopy (FAAS). The digestion was carried out in triplicate for the blank, standard and samples. Digestion of a reagent blank was also performed in parallel with milk samples keeping all digestion parameters the same for heavy metals determination. (Ogabielaet. al., 2010).

\section{RESULTS AND DISCUSSION}

\subsection{Lead Concentrations in BCM and UCM}

As indicated by data in table 1.1 and 1.2, the mean concentrations of lead was in the range of $0.0009-$ $0.0014 \mathrm{ppm}$ with the highest mean concentration from brand 5 and lowest from brand 1 of the BCM and the elemental concentrations of BCM and UCM are presented in Fig 1 and 2. The highest mean concentration of lead in UCM was recorded in the samples from Panteka $(0.003133 \mathrm{ppm})$. The lowest concentration of was recorded in the samples from Kasuwar Magani $(0.001633 \mathrm{ppm})$. The mean concentrations of lead in this study were lower than those reported by Ogabiela et al.,(2010) in the assessment of metal levels in Challawa Industrial area of Kano state and Zaria, Tasseet al., (2014) determination of concentrations of selected heavy metals in cow's milk: borena zone, Ethiopia and Bilandžić et al., (2011) in the northern and southern Croatia, Mahmud et al., (2017) recorded lead below detection level in cow milk samples at Kawo, Kudenda and above the permissible limit at Malali in Kaduna, , while high levels of lead were reported in Egypt by Abdallah, (2011). The levels of lead in milk samples from both UCM and BCM were within the acceptable limit of lead for milk and dairy product taken as 0.02 ppmas stipulated by Nigerian Industrial Standard on Cow Milk.

Table 1.1. Lead Metal Concentration (ppm) from BCM

\begin{tabular}{|l|l|l|l|l|l|}
\hline SAMPLE & Brand 1 & Brand 2 & Brand 3 & Brand 4 & Brand 5 \\
\hline 1 & 0.0009 & 0.0014 & 0.0022 & 0.002 & 0.0012 \\
\hline 2 & 0.0008 & 0.0012 & 0.0016 & 0.0022 & 0.0014 \\
\hline $\begin{array}{l}\text { Mean } \pm \\
\text { Std }\end{array}$ & 0.001 & 0.002 & 0.0012 & 0.0016 & 0.0016 \\
\hline
\end{tabular}

Table2. Lead Metal Concentrations (ppm) from UCM

\begin{tabular}{|c|c|c|c|c|c|c|c|c|}
\hline $\begin{array}{l}\text { Sample } \\
\text { Location }\end{array}$ & Panteka & $\begin{array}{l}\text { Railway } \\
\text { Market }\end{array}$ & Rido & $\begin{array}{l}\text { Kasuwar } \\
\text { barchi }\end{array}$ & $\begin{array}{l}\text { Zango } \\
\text { cattle } \\
\text { market }\end{array}$ & Kajuru & $\begin{array}{l}\text { Abubakar } \\
\text { Gummi } \\
\text { Market }\end{array}$ & $\begin{array}{l}\text { Kasuwar } \\
\text { Magani }\end{array}$ \\
\hline 1 & 0.004 & 0.0016 & 0.0026 & 0.0002 & 0.0032 & 0.0021 & 0.0036 & 0.003 \\
\hline 2 & 0.003 & 0.0006 & 0.0024 & 0.0006 & 0.0024 & 0.0014 & 0.0026 & 0.001 \\
\hline 3 & $0.0024 \mathrm{ii}$ & 0.0021 & 0.0021 & 0.0014 & 0.0021 & 0.0018 & 0.002 & 0.0009 \\
\hline $\begin{array}{l}\text { Mean } \pm \\
\text { Std }\end{array}$ & $0.003133 \pm 0.000808$ & $\begin{array}{l}0.001433 \pm \\
0.000764\end{array}$ & $\begin{array}{l}0.002367 \pm \\
0.000252\end{array}$ & $\begin{array}{l}0.000733 \pm \\
0.000611\end{array}$ & $\begin{array}{l}0.002567 \pm \\
0.000569\end{array}$ & $\begin{array}{l}0.001767 \pm \\
0.000351\end{array}$ & $\begin{array}{l}0.002733 \pm \\
0.000808\end{array}$ & $\begin{array}{l}0.001633 \\
\pm \\
0.001185\end{array}$ \\
\hline
\end{tabular}




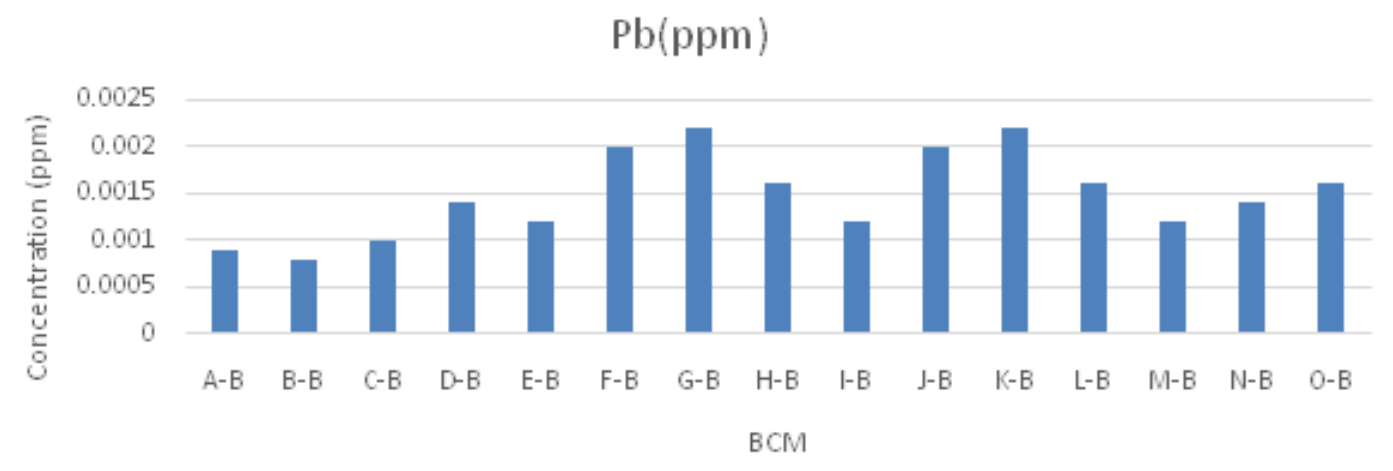

Fig1. Elemental concentrations (ppm) of Pbin BCM

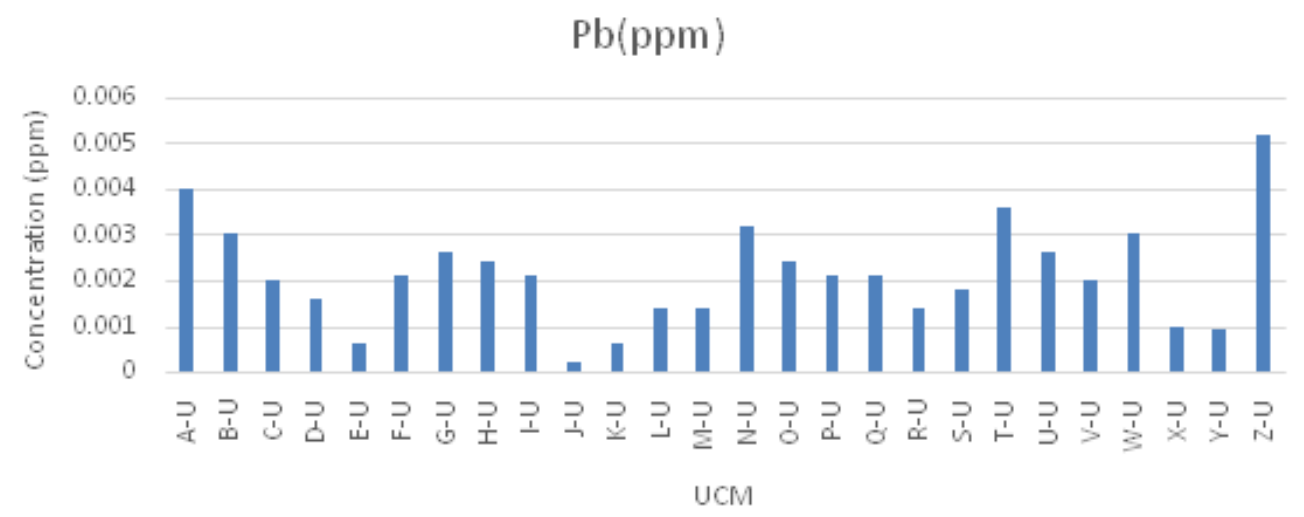

Fig2. Elemental concentrations (ppm) of $\mathrm{Pb}$ in UCM

This study suggest that lead is detected in milk in most of the studied BCM and UCM samples particularly those areas where metals are fabricated and processed like Panteka, lead is also detected in other unsuspecting brands and areas like Rido, Kasuwar Barchi and Kajuru. These are areas where little or no industrial activity exist however, This could be due to fodder contamination, climatic factors such as wind, use of Agro-chemicals and very importantly drinking water. Furthermore, these cows graze along rail lines, roadsides etc. lead which is a fuel additive could be emitted from the car exhaust to contaminate the environment (Ogabiela et al., 2010). Lead is one of the limited classes of element that can be described as purely toxic. Most other elements thought toxic at high concentration are actually required nutrient at lower levels. There is no exposure level below which lead appears to be safe. High level of lead is particularly of great concern especially due to the fact that milk and dairy products are consumed mostly by infants and children who are uniquely susceptible to the effect of lead (Ogabiela et al., 2010). Lead absorption constitutes serious risk to public health. It induces reduced cognitive development and intellectual performance in children, increased blood pressure, and cardiovascular diseases in adult as well as liver and kidney malfunctioning (Ogabiela et al., 2010).

\subsection{Cadmium Concentrations in BCM and UCM}

The mean concentrations of cadmium obtained in this research ranges from $0.0007-0.003267 \mathrm{ppm}$ for BCM and $0.00013-0.0032 \mathrm{ppm}$ for UCM the values obtained where all within the limit of $0.2 \mathrm{ppm}$ as specified by the Nigerian Industrial Standards for cow milk, Fig 3 and 4 shows elemental concentrations of Cadmium in BCM and UCM, it is also within the limit of the recommended dietary allowance given as $0.5 \mathrm{mg} / \mathrm{day}$ (Mahmud et al.,2017).Similar levels was reported by Hasan and Arzu (2012) in Samsung region of Turkey. Renata et al., (2013) recorded lower levels of lead and Cadmium in Simmental cow milk, however higher values were reported by Mahmud et al., 2017 in the analysis of selected heavy metals in cow milk in kudenda, Malali and Kawo areas of Kaduna state. This suggest that the environment, air and the feeds the animal ingest is not contaminated with cadmium. However bio accumulation may occur with continues ingestion of small amount of cadmium as the metal is not biodegradable. Sample X-U of Kasuwar Magani was found to be at 
Quantitative Analysis of Selected Heavy Metals in Samples of Branded and Unbranded Cow Milk in Selected Areas of Kaduna Metropolis

unsafe levels (fig 3),this may be attributable to anthropogenic activities via industrial discharges, emissions and inorganic fertilizer that may pollute the environment, air and water bodies which indirectly or directly get to the fodder of the animals (Ogabiela et al 2010). A high levels of Cd in cow milk was reported by Ogabiela et al., (2010), Blandzic et al., (2011), Abdulkhaliq et al.,(2012) and Tassew et al., (2015) .

Regular absorption of cadmium causes damage to the proximal renal tubules and calcium, phosphorus, glucose, amino acid and small peptides are loss in the urine. Once cadmium accumulates in tissues it cannot be removed safely by chelation therapy without causing kidney damage (Mahmud et al., 2017) Cadmium affects calcium metabolism and skeletal changes resulting from calcium loss and ends in a decrease bone mineral density (Mahmud et al., 2017).

Table3. Cadmium Metal Concentration (ppm) from BCM

\begin{tabular}{|l|l|l|l|l|l|}
\hline \multicolumn{1}{|c|}{ SAMPLE } & \multicolumn{1}{|c|}{ Brand 1 } & \multicolumn{1}{c|}{ Brand 2 } & \multicolumn{1}{c|}{ Brand 3 } & \multicolumn{1}{c|}{ Brand 4 } & \multicolumn{1}{c|}{ Brand 5 } \\
\hline 1 & 0.0009 & 0.001 & 0.0013 & 0.007 & 0.0014 \\
\hline 2 & 0.0007 & 0.0019 & 0.0018 & 0.0009 & 0.0011 \\
\hline 3 & 0.0005 & 0.0015 & 0.0016 & 0.0019 & 0.0012 \\
\hline Mean \pm & $0.0007 \pm$ & $0.001467 \pm$ & $0.001567 \pm$ & $0.003267 \pm$ & $0.001233 \pm$ \\
Std & 0.0002 & 0.000451 & 0.000252 & 0.003272 & 0.000153 \\
\hline
\end{tabular}

Table4. Cadmium Metal Concentration (ppm) from UCM

\begin{tabular}{|c|c|c|c|c|c|c|c|c|}
\hline Sample & Panteka & $\begin{array}{l}\text { Railway } \\
\text { Market }\end{array}$ & Rido & $\begin{array}{l}\text { Kasuwar } \\
\text { Barchi }\end{array}$ & $\begin{array}{l}\text { Zango } \\
\text { Cattle } \\
\text { Market }\end{array}$ & Kajuru & $\begin{array}{l}\text { Abubakar } \\
\text { Gummi } \\
\text { Market } \\
\end{array}$ & $\begin{array}{l}\text { Kasuwar } \\
\text { Magani }\end{array}$ \\
\hline 1 & 0.001 & 0.0009 & 0.0017 & 0.0005 & 0.0017 & 0.0014 & 0.0018 & 0.0019 \\
\hline 2 & 0.0019 & 0.007 & 0.0011 & 0.0013 & 0.0017 & 0.0016 & 0.0019 & 0.0009 \\
\hline 3 & 0.0009 & 0.0017 & 0.0012 & 0.00017 & 0.0015 & 0.0019 & 0.0022 & 0.0055 \\
\hline $\begin{array}{l}\text { MEAN } \pm \\
\text { Std }\end{array}$ & $\begin{array}{l}0.001267 \pm \\
0.000551\end{array}$ & $\begin{array}{l}0.0032 \pm \\
0.003315\end{array}$ & $\begin{array}{l}0.001333 \pm \\
0.000321\end{array}$ & $\begin{array}{l}0.000657 \pm \\
0.000581\end{array}$ & $\begin{array}{l}0.0016 \pm \\
0.000141\end{array}$ & $\begin{array}{l}0.001633 \pm \\
0.000252\end{array}$ & $\begin{array}{l}0.001967 \pm \\
0.000208\end{array}$ & $\begin{array}{l}0.002767 \pm \\
0.002419\end{array}$ \\
\hline
\end{tabular}

\section{$\mathrm{Cd}(\mathrm{ppm})$}

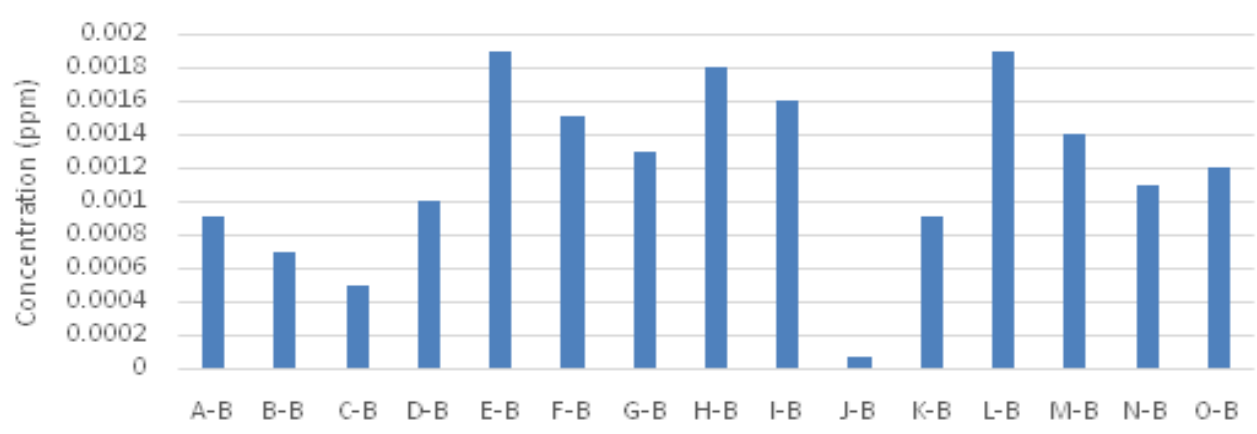

Fig3. Elemental concentrations (ppm) of $C d$ in $B C M$

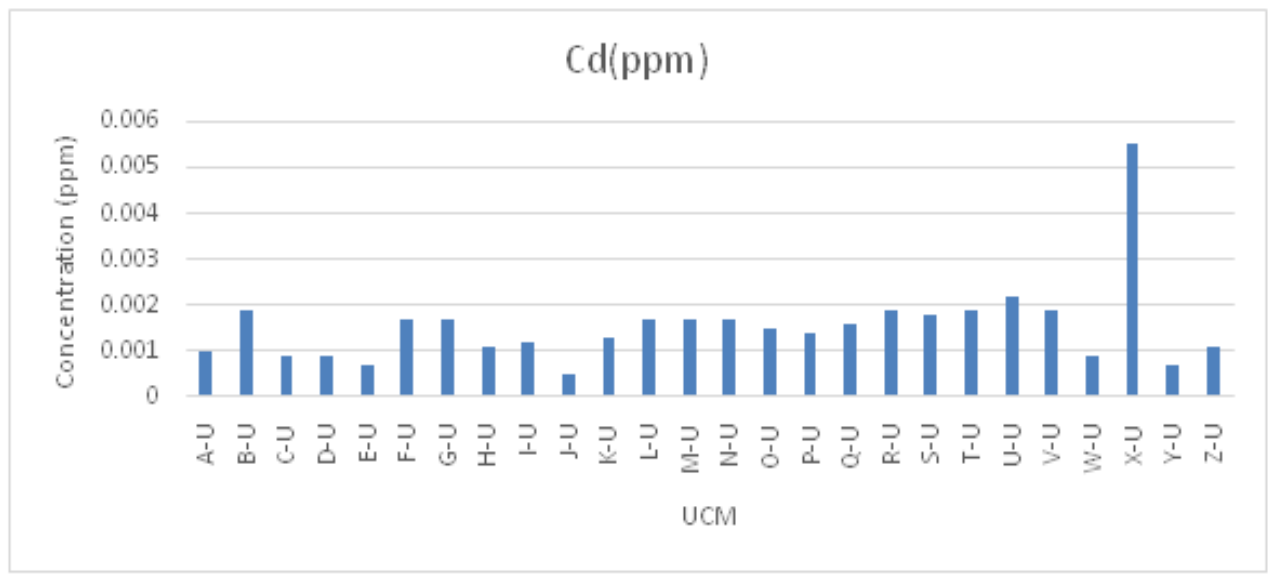

Fig4. Elemental distribution of $C d$ (ppm) in UCM 
Quantitative Analysis of Selected Heavy Metals in Samples of Branded and Unbranded Cow Milk in Selected Areas of Kaduna Metropolis

\subsection{Chromium Concentrations from BCM and UCM}

The average levels of $\mathrm{Cr}$ in milk samples analyzed from UCM and BCM from the investigation is shown in table 1.5 as $0.0028 \mathrm{ppm}$ and $0.0015 \mathrm{ppm}$ respectively. The highest concentration recorded was $0.002367 \mathrm{ppm}$ and the lowest concentration $0.000533 \mathrm{ppm}$ for the various brands of BCM considered. While the concentrations recorded for UCM is in the range of $0.000933-0.0032 \mathrm{ppm}$, Mahmud et al.,(2017) found chromium below detection limit in the determination of heavy metals in cow milk in selected areas in Kaduna metropolis. Higher concentrations were recorded by Ogbabiela et al., (2010) in Kano, Tassew et al.,(2015) in Ethopia and Ruqia et al.,(2015) in Pakistan.

Chromium is a useful mineral in the body found in the blood and hair, it aids in proper functioning of insulin and blood cholesterols. There is no data available for the maximum limit of chromium in milk (Tassew et al., 2014). However, daily intake of chromium intake of 50- $200 \mu \mathrm{g} / \mathrm{day}$ is acceptable by WHO. Lower availability of chromium in the body can lead to skin irritation, and ulceration. However excessive amount of $\mathrm{Cr}$ in the body can cause kidney and liver failure, circulatory and nerve tissue problems (Lentech, 2004).

Table5. Chromium Metal Concentration of BCM

\begin{tabular}{|l|l|l|l|l|l|}
\hline SAMPLE & Brand 1 & Brand 2 & Brand 3 & Brand 4 & Brand 5 \\
\hline 1 & 0.0004 & 0.0017 & 0.0008 & 0.0014 & 0.0012 \\
\hline 2 & 0.0006 & 0.0028 & 0.0012 & 0.0012 & 0.0011 \\
\hline 3 & 0.0006 & 0.0026 & 0.0014 & 0.0024 & 0.001 \\
\hline Mean \pm & $0.000533 \pm$ & $0.002367 \pm$ & $0.001133 \pm$ & $0.001667 \pm$ & $0.0011 \pm$ \\
Std & 0.000115 & 0.000586 & 0.000306 & 0.000643 & $1 \mathrm{E}-04$ \\
\hline
\end{tabular}

Table6. Chromium Metal Concentration of UCM

\begin{tabular}{|c|c|c|c|c|c|c|c|c|}
\hline $\begin{array}{l}\text { SAMP } \\
\text { LE }\end{array}$ & Panteka & $\begin{array}{l}\text { Railway } \\
\text { Market }\end{array}$ & Rido & $\begin{array}{l}\text { Kasuwar } \\
\text { barchi }\end{array}$ & $\begin{array}{l}\text { Zango } \\
\text { Cattle } \\
\text { Market }\end{array}$ & Kajuru & $\begin{array}{l}\text { Abubakar Gummi } \\
\text { Market }\end{array}$ & $\begin{array}{l}\text { Kasuwar } \\
\text { Magani }\end{array}$ \\
\hline 1 & 0.0018 & 0.0018 & 0.0017 & 0.0026 & 0.0028 & 0.0017 & 0.003 & 0.0017 \\
\hline 2 & 0.0006 & 0.0016 & 0.0016 & 0.0028 & 0.0024 & 0.0016 & 0.0022 & 0.0062 \\
\hline 3 & 0.0004 & 0.003 & 0.0084 & 0.0009 & 0.0038 & 0.0023 & 0.0044 & 0.0058 \\
\hline Mean \pm & $0.0009 \pm$ & $0.002133 \pm 0.0$ & $0.0039 \pm 0.0$ & $0.0021 \pm$ & $0.003 \pm$ & $0.001867 \pm$ & $0.0032 \pm$ & $0.004567 \pm$ \\
\hline Stdev & 0.000757 & 00757 & 03897 & 0.001044 & 0.000721 & 0.000379 & 0.001114 & 0.002491 \\
\hline
\end{tabular}

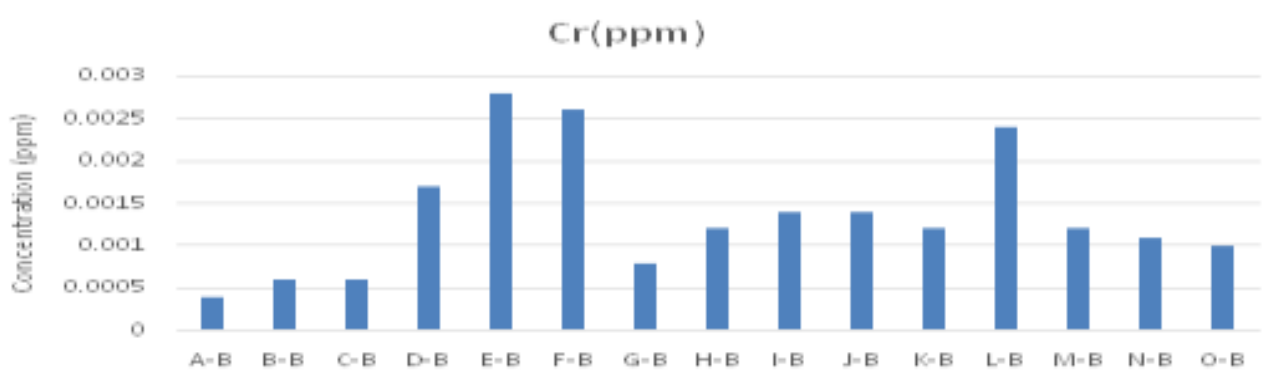

Fig 5. Elemental concentrations (ppm) of $\mathrm{Cr}$ in BCM

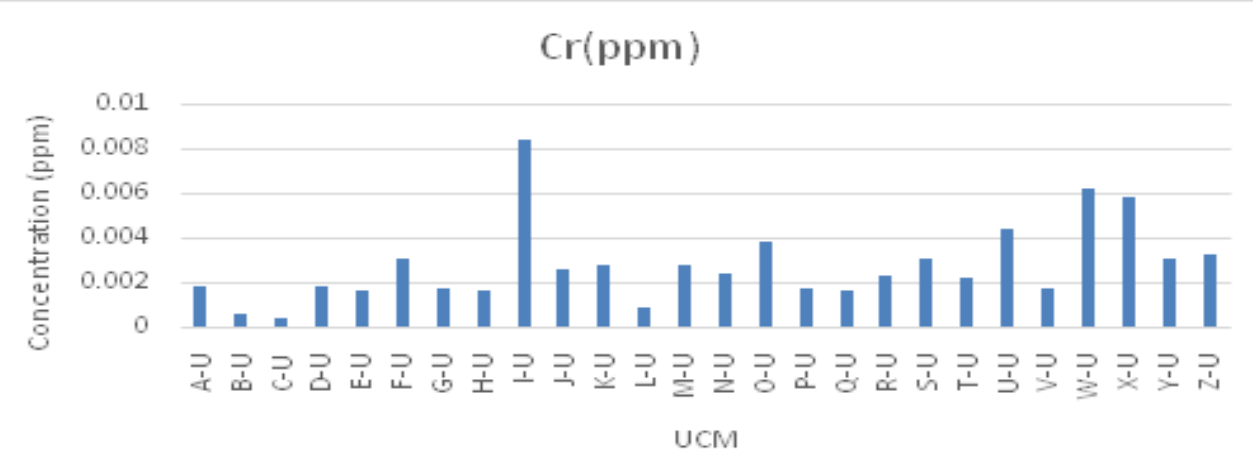

Fig6. Elemental distribution of $\mathrm{Cr}(\mathrm{ppm})$ in $\mathrm{UCM}$ 


\subsection{Comparison of $\mathrm{Pb}, \mathrm{Cd}$ and $\mathrm{Cd}$ in $\mathrm{BCM}$ and $\mathrm{UCM}$}

The UCM has higher concentration of lead cadmium and chromium as shown in the elemental distribution in fig. 7 and 8 . This could be due to fodder contamination, climatic factors such as wind, use of Agro-chemicals and very importantly drinking water (Ogabielaet al., 2010). Furthermore, these cows graze along rail lines, roadsides etc. lead which is a fuel additive could be emitted from the car exhaust to contaminate the environment (Ogabielaet al.,2010).

\section{Elemental Concentration of Heavy Metals in BCM}

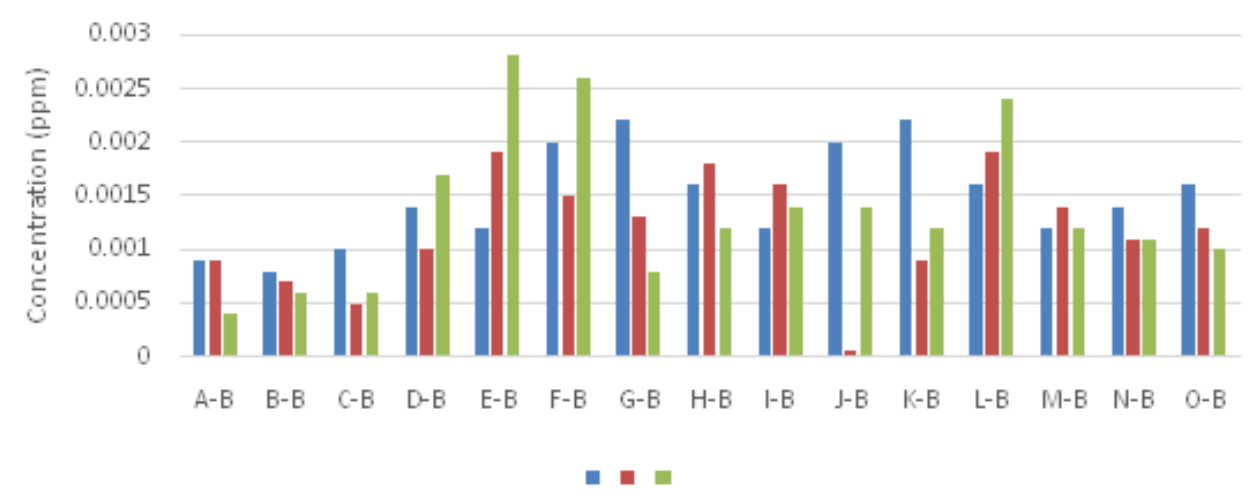

Fig7. Comparison of concentrations (ppm) of heavy metals of all BCM samples

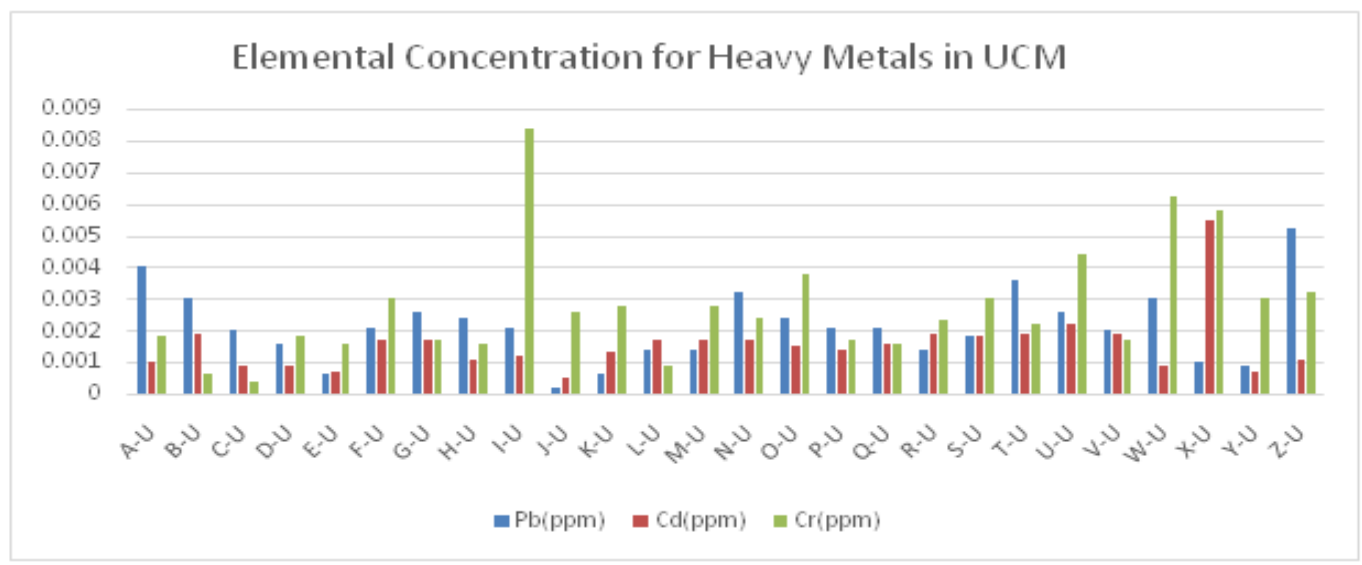

Fig8. Comparison ofconcentrations (ppm) of $\mathrm{Pb}, \mathrm{Cd}$ and $\mathrm{Cr}$ in $\mathrm{UCM}$

\section{Conclusion}

In this present study, the concentration of $\mathrm{Cr}, \mathrm{Cd}$ and $\mathrm{Pb}$ were analyzed in cow milk samples collected from different markets within Kaduna metropolis. The results revealed that the levels of Lead, Cadmium and Chromium in the studied BCM and UCM samples collected within Kaduna metropolis were found to be within the limit specified by the Nigerian Industrial Standards on cow milk, WHO and the recommended dietary allowance except for cadmium metal in one of the UCM samples. The results also shows the consumption of Chromium via all samples was much higher than that of Lead and Cadmium.

\section{REFERENCES}

[1] Abdulkhaliq, A., Swaileh, K. M., Hussein, R. M. andMatani, M.(2012). Levels of metals (Cd, Pb, Cu and $\mathrm{Fe}$ ) in cow's milk, dairy products and hen's eggs from the West Bank, Palestine, International Food Resource Journal, 19(4) 1039 -1047.

[2] Adams, M.J. and Moss M.O. (1995). Food Microbiology. New Age International Publisher Limited, New Delhi. pp $64-66$.

[3] Adeneye, J. A. (1989). Variations in yield and composition of milk from different quarters of lactating White Fulani cattle in a tropical environment. Nigerian Journal of Animal Production, 16:8-15.

[4] Alfa, L. (1987). Dairy Handbook. (2) New Age International Publisher Limited, London, pp 23 -27. 
Quantitative Analysis of Selected Heavy Metals in Samples of Branded and Unbranded Cow Milk in Selected Areas of Kaduna Metropolis

[5] Armstrong, H. C (1995). Food and nutrition (3) New Age International Publisher Limited, London pp 69 70

[6] Bilandžić, N., Dokić, M., Sedak, M., Božica, S., Varenina, I. and Knežević, Z.(2011). Trace element levels in raw milk from northern and southern regions of Croatia. Food Chemistry. 127(1) 63-66. doi: 10.1016/j. 2010.12.084.

[7] Farid, S. M., Enani, M. A. and Wajid, S. A.,(2004). Determination of trace elements in cow's milk in Saudi Arabia., JKAUEngineeringScience., 15(2), 131-140

[8] González-Walez, J. R., Senís, E., Gutiérrez, A.and Prieto, F. (2012). Cadmium and lead in bovine milk in the mining area of the Caudal River (Spain) Environmental Monitoring and Assessment, 184(7):40294034.doi: 10.1007/s10661-011-2241-1.

[9] Hasan, T. and Arzu S.(2012). Heavy metal concentrations in raw milk collected from different regions of Samsun, Turkey. International Journal of Dairy Technology 65 (4):516-522.

[10] Lenntech, (2004). Water Treatment and Purification, Lenntech, Rotterdamseweg, Netherland. 54 - 60

[11] Lopez, C. E. L., Ramos, L. L., Ramadan, S. S. and Bulacio, L. C., (2003). Presence of aflatoxinM1 in milk for human consumption in Argentina. Food Control: 14, (31-34)

[12] Mahmud, M. I., Muhammad, Z. andZakari A. (2017). Determination of Some Heavy Metals in Milk of Cow Grazing At Selected Areas, of Kaduna Metropolis. International Journal of Advanced Research in Computer Science and Software Engineering a(716)/01617, 341-346.

[13] Malhat, F., Hagag, M., Saber, A., and Fayz, A.E(2012). Contamination of Cows milk by heavy metal in Egypt. Bulletin of Environmental Contamination and Toxicology. 88(4):611-613.

[14] Ogabiela,E.E, UdibaU.U, Adesina,O.B, Hammuel, C., Ade-Ajayi, F., A., Yebpella,G.G., Mmereole,U.J. and Abdullahi, M.(2010). Assessments of metals levels in fresh milk from cows grazed around Challawa Industrial Estate Kano,Journal of Basic and AppliedScienceResource. 1(7):533-538 2011.

[15] Renata, P. Jerzy, W., Paweł, C., Piotr, S.,Bogumiła, P. and Agnieszka (2013).Concentrations of toxic heavy metals and trace elements in raw milk of Simmental and Holstein-Friesian cows from organic farm.National Center for Biotechnology Information (NCBI).185(10): 8383-8392.

[16] Ruqia, N., Muslim, K., Hameed, U. and Muhammad, M.,(2015). Comparative Study of Heavy Metals (Ni, $\mathrm{Cu}, \mathrm{Fe}$ and $\mathrm{Cr}$ ) in the Milk of Cattle and Humans Collected from Khyber Pakhtunkhwa, PakistanGlobal Veterinaria14 (5): 761-767, 2015 ISSN 1992-6197DOI: 10.5829/idosi.gv.2015.14.05.9417

[17] Swarup, D., Patra, R. C., Naresh, R., Kumar, P. and Shekhar, P. (2005). Blood lead levels in lactating cows reared around polluted localities; transfer of lead into milk. Science of the Total Environment.347 (13):106-110. doi: 10.1016/j.scitotenv.2004.12.055.

[18] Tripathi,R. M., Raghunath, R., Sastry,V. N. and Krishnamurthy T. M. (1999). Daily intake of heavy metals by infants through milk and milk products. Science of the Total Environment. 1999; 227(2-3):229-235. doi:10.1016/S0048-9697(99)00018-2. Vromman V.

[19] Tassew, B, Ahmed, H. and Vegi M.(2015). Determination of Concentrations of Selected Heavy Metals in Cow's Milk: Borena Zone, Ethiopia. Journal of Health Science 2014, 4(5): 105-112 DOI: 10.5923/j.health. 20140405.01

Citation: I.Sani, B El-yaqub, SO Okeniyi, AB Shehu. "Quantitative Analysis of Selected Heavy Metals in Samples of Branded and Unbranded Cow Milk in Selected Areas of Kaduna Metropolis”. International Journal of Research Studies in Biosciences. 2020; 8(9): 1-7. DOI: https://doi.org/10.20431/2349-0365.0809001.

Copyright: (C) 2020 Authors. This is an open-access article distributed under the terms of the Creative Commons Attribution License, which permits unrestricted use, distribution, and reproduction in any medium, provided the original author and source are credited. 